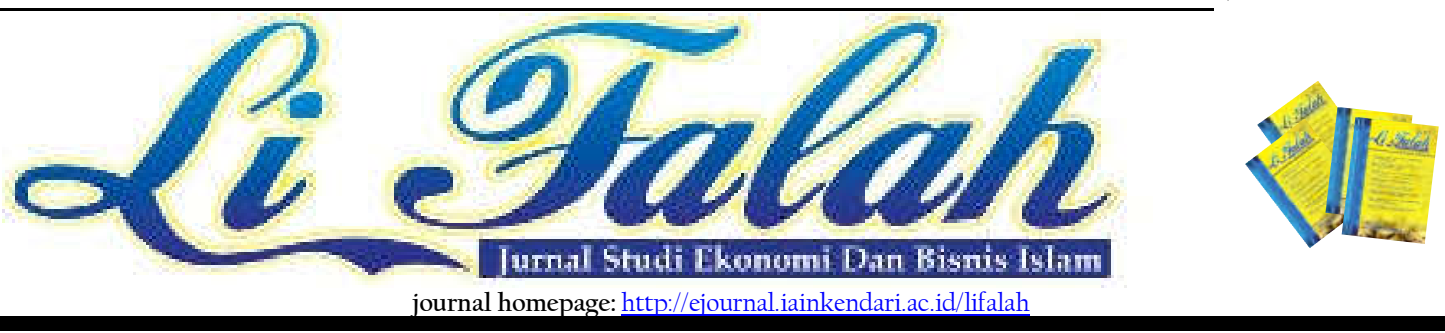

\title{
Waqf Conflict Resolution Through Mediation (Islamic And Bugis Norm Perspective)
}

Muhammad Majdy Amiruddin and Yunus Shamad

${ }^{1}$ IAIN Parepare

Email: majdiamiruddin@stainparepare.ac.id

INFO ARTIKEL

Keywords:

ADR, Dispute, Waqf, Mediation

DOI:

http://dx.doi.org/10.31332/lifalah.v4il.1373
A B S T R A C T

The purpose of this study is to identify the causes of disputes and to describe the dispute resolution process through non-litigation mediation in Islamic and Local Norm Perspective. The type of research that compilers use is field research, namely by obtaining data from interviews, observations, and related file searches. Furthermore, this research is supported by library research as a complement. The approach in this study is a juridical-empirical approach. The results of the study concluded that The dispute that occurred was related to the status of the land that was built on top of the Madrasah DDI Labukkang. The cause of the dispute is based on two theories, the theory of Principle negotiation and the Theory of basih human needs. The mediation process is carried out through 3 stages. First is pre-mediation. Mediation conducts the plans related to the preparation of mediation. Second is the execution of mediation. The mediator presents the disputing parties, gives an opportunity to all parties to provide information. The last is the emplementation of mediation. From the syariah perspective, the mediation complies with the 12 basic principles in Islamic Mediation. From the Bugis Norms, it complies with the five norms called pangngadareng.

\section{Introduction}

For most of the people of Indonesia, land occupies an important position in daily life, moreover, for rural people whose main work is farming, gardening or farming. Land tenure in the countryside concerns various aspects such as economic, demographic, legal, political and social aspects (Wiradi \& Tjondronegoro, 1984). 
Among human relations with religious lands, there is an institution of land rights called the waqf land. waqf taken from the Arabic verb waqafa, according to language means to hold or stop. In Islamic law endowment means giving up a long-lasting property rights to someone or Nadzir either in the form of individuals or in the form of a management body provided that the results or benefits are used for things that are in accordance with Islamic Shari'a teachings. Assets that have been represented, out of ownership rights that are inherited, and not also the property of Nadzir or the place of submission, but are the right of God in terms of the rights of the general public.

Disputes over waqf land are a sure thing. In various Islamic boarding schools in Indonesia, especially in South Sulawesi, many cases of disputes over waqf land have occurred. In conditions where the value and use of land is larger and wider as it is today, it allows endowments to become legally unclear. This also creates vulnerability and facilitates deviations from the legal nature and purpose of the representative, such as the existence of waqf land which is no longer known, the existence of waqf land that seems to have belonged to the wakif or nadzir heirs, the existence of disputes and claims against waqf lands and various other cases of waqf land.
As one of the largest and oldest Islamic education institutions in South Sulawesi, Darud Dakwah wal Irsyad (DDI) also often experiences disputes over land which are used as the location for conducting education. One of the madrasas under the auspices of DDI who experienced this was the DDI Labukkang Islamic Boarding School.

From various scientific works in the form of the results of research that have been done before, researchers found writings and literature in the form of books whose studies have relevance to the problems in this study include::

1. "Penyelesaian sengketa wakaf dalam Hukum positif", written by Junaidi Abdullah and Nur Qodin in the journal Journal, ZISWAF, Vol. 1, No. 1, June 2014 STAIN Kudus. This study discusses settlement of waqf disputes with Settlement of waqf disputes based on Indonesia's positive legal tradition. The equation with this research is the legal approach in resolving conflict between representatives. The difference is in the traditional values adopted by the Bugis community in solving problems.

2. Sengketa tanah wakaf dan strategi penyelesaiannya, written by Nur Fadhilah in Jure Journal, Sharia Journal and Law, Volume 3 Number 1 , June 2011, Tulungagung State Islamic 
College. The study discusses several factors that cause waqf conflicts based on Ralf Dahrendorf's conflict resolution theory and its resolution strategies based on the perspective of waqf regulations. The study of this paper concludes that resourses, interests or needs, values, relationships and information including structure are some of the trigger factors of waqf conflict. Bringing problems or waqf conflicts to court is the last strategy of resolving the conflict. In contrast to the research carried out by researchers in the settlement of complications, it will use the ADR (Alternative Dispute Resolution) approach in various forms, such as: mediation, negotiation, arbitration, and conciliation and local genius.

The thesis of Naomi Helena Tambunan "Peran Lembaga Mediasi In Settling Land Disputes Organized by the Jambi Municipal Land Office ". In this thesis discussing about land disputes is basically not all can be solved by a mediation process. However, in each dispute between personal / individual interests, mediation can be sought, even though in reality the land dispute, one of which is a legal entity / company, mediation outside the court is still being sought as the first attempt. Regarding land disputes categorized by the
National Land Agency as a case that can be pursued by the mediation process, the completion of this process is an effective thing, and a good breakthrough in efforts to resolve land disputes in Indonesia. Given that each party does not need to deal with the court, and the dispute settlement agreement (mediation) directly becomes the basis for the legalization of assets or requests for land services at the local Land Agency Office, mediation addresses community needs in obtaining services in the land.

\section{Research Methods}

\subsection{Types of Research}

This research is included in the category of field studies (filed resesearch) (Sutrisno et al, 2004), referring to the collection of field data from observations, which will be used as research material in accordance with the study material. Basically this research is a qualitative research that attempts to describe, analyze, and interpret data collected in the research process (Mardalis, 2004). In order to maintain the objectivity of the research, the collected data will be processed according to qualitative methods. The process of analyzing data that has been processed is by using content analysis techniques (content analysis). Data that has been obtained will be processed and directed in accordance with the prepared concept. The 
next step is the reconstruction of the implementation of waqf land in Darud Da'wah Wal-Irsyad (DDI) Madrasah in Parepare City as a conceptual contribution that can be used as a reference and can be applied by anyone who has an interest in dealing with conflicts over waqf land not only in Parepare City, but in other cities or regions. This qualitative research emphasizes the exploration process of representatives and handling conflicts in terms of mediation approaches that are in accordance with social, political and legal conditions for waqf lands in DDI Madrasas in Parepare. Processing data obtained from the field by correlating with various concepts of resolution according to experts and implemented in practice the settlement in the City of Parepare in accordance with contemporary social reality.

\subsection{Research Approach}

The research used in this study is descriptive research using a qualitative approach, where the data obtained later is not in the form of numbers but in the form of words. Descriptive research is research that is intended to provide data as thorough as possible about humans, circumstances, or other symptoms. The point is primarily to reinforce the hypotheses, so that they can strengthen old theories, or within the framework of compiling new theories. In this study described the causes of disputes and civil dispute resolution process in Labukkang DDI Madrasah by means of non-litigation mediation.

\subsection{Techniques for Determining Respondents}

In general there are two techniques for determining respondents or sampling that can be used, namely probability sampling which tends to be quantitative with statistical analysis, and non-probability sampling techniques that tend to be qualitative. To answer specific problems that are difficult to disclose and not easily analyzed statistically, non-probability sampling techniques will be more appropriate and can be more useful in the process of collecting data. Non-probability sampling techniques aim to identify things that are still unclear in the preliminary research, to get an idea of a collection of observation units which are then used as the basis for the application of more precise and accurate probability samples.

Because the researcher wants to identify things that are not clear about the right respondent as an informant, then the determination of the informant is the result of recommendations from previous informants. The technique commonly is known as snowball technique.

\subsection{Data Source}

The source of the data obtained consists of two, namely primary and 
secondary data. First is primary data sourced from field research called field research. Primary data is sourced from the DDI Labukkang Madrasah Principal, Bapak Sinar and Imam Mesjd Nurul Huda Labukkang, Ustaz Said. Other primary data is sourced from the Wakif and Nadzir of DDI Madrasah in Parepare City and other related institutions. Each informant mentioned was questioned to find out data about waqf and its management in the City of Parepare.

In addition to the first primary data source, the second data source, which is secondary, is the finding of data from various literature review studies called library research obtained by searching for keywords through catalogs and indices. Then look for data through bibliogarfi which are published in special themes.

\subsection{Collecting Data}

Collecting data in a field study is one very important step. In general, data collection methods or techniques have many ways, as stated by Suharsimi Arikunto, that data collection can include (a) using tests; (b) using the interview method; (c) use the observation method; (d) using the documentation method. Of these methods, the authors used in this study are:

\section{Observation}

Observation is used in order to collect data in a study, which is the result of active and attentive actions of the soul to be aware of something that is desired. In this case, Mardalis said, that observation is a deliberate and systematic study of social conditions or phenomena and psychological symptoms by observing and taking notes. Furthermore, according to Moh. Nazir said that observation is a way for other standard tools for this purpose, and according to Sutrisno Hadi, observation is to conduct research as well as observation of problems that have to do with scientific work (Hadi, 1987).

From the several definitions above, it is understood implicitly that observation or observation is to see and come directly to a research location. The research locations visited were the Labukkang DDI Madrasah in Parepare City and Nurul Huda Labukkang Mosque. Interview / Interview

One method of data collection is by interviewing, which is getting information by 
asking the respondent directly. Masri Singarimbun states that interviews are a process of interaction and communication. Furthermore, it is explained again, that in this process, the results of interviews are determined by several factors that interact and influence the flow of information. These factors are interviewers, informants, respondents, research topics contained in the questionnaire, and interview situations.

It can be understood that interviews are one form or instrument that is often used in research or in data collection, whose purpose is to obtain information directly from the informant. Therefore, if this technique is used in research, it is necessary to know the goals, intentions and problems needed by the researcher first. In this case, the target or object of the interview is the Head of the Labukkang DDI Madrasah School and the Management of the Nurul Huda Labukkang Mosque.

\section{Documentation}

The documentation method that the author did in this study was to retrieve data at the study site. The most important documentation data is data about documents related to DDI madrasa land in Parepare City.

\subsection{Data Analyses Technique}

The data obtained in this study is processed qualitatively because this research provides an overview of the situation and events factually and systematically regarding the factors, traits, and relationships between the phenomena that are owned. After being processed qualitatively, then systematically analyzed the records of observations of written data and unwritten data, as well as predicting the results of interviews. The collected data is described as findings in the research report. The procedure for processing data while in the field is analyzed interactively and continues continuously to completion, which consists of three activities, namely data reduction, data display and conslusion drawing / verification. The third series of data analysis techniques activities the authors apply as follows:

\section{Data Reduction}

Data reduction means summarizing, choosing the main things, focusing on important things, looking for themes and patterns and disposing of unnecessary ones. In the research 
that the authors do, the data obtained from the field is quite large, so it needs to be carefully and detailed. . Because the longer the author is in the field, the more data will be complex and complicated. For this reason, it is necessary to immediately analyze the data through data reduction. Thus the data that has been reduced will provide a clearer picture, and make it easier for the author to do further data collection, and look for it if needed. Data reduction results leave data related to the cause of the dispute and the dispute mediation process.

\section{Data Display}

In qualitative research, the presentation of data is done in the form of brief descriptions, charts, relationships between categories, flowcharts and the like. By displaying the data it will be easier to understand what is happening, plan the next plan based on what has been understood because the method used in this study is descriptive analytical, so the data display carried out is mostly poured into a brief description.

\section{Conclusion}

\section{Drawing/Verification}

The third step in analyzing qualitative data is drawing conclusions and verification. Conclusions obtained from the previous stage, then analyzed by descriptive-exploratory techniques, and using inductivequalitative methods. That is, beginning with revealing specific facts based on opinions and actions of the subjects of research in wakif and nadzir in the city of Parepare based on reality. general facts that can be concluded as research findings.

\section{Results and Discussion}

\subsection{Waqf Resolution Conflict through Mediation}

\subsubsection{Waqf Conflict}

The term "conflict" etymologically comes from Latin "con" which means together and "fligere" which means collision or collision (Setiadi \& Kolip, 2011). In general, the term social conflict contains a series of phenomena of conflict and conflict between individuals through class conflicts to international conflicts and conflicts. Coser defines social conflict as a struggle against values and recognition of rare status, then power and sources of 
opposition are neutralized or carried out or eliminated by rivals (Zeitlin, 1998).

Conflict means disputes, disputes and conflicts. Whereas social conflict is a conflict between members or the community that is comprehensive in life. Conflict is the process of achieving goals by weakening the opponent, without regard to the prevailing norms and values. In another sense, conflict is a social process that takes place by involving people or groups that challenge each other with the threat of violence (Narwoko \& Suyanto, 2005).

The dispute that occurred in this study was a dispute over the land used by the Labukkang DDI madrasa. DDI Madrasah and Nurul Huda Mosque are in the same area. The status of this land is a conflict between the parties to the dispute. The disputing parties were first, the Parepare DDI Management and some of the Nurul Huda Labukkang Mosque Managers. This party wants that the status of the DDI Labukkang madrasah should be the property of DDI. During this time the madrasa did not get optimal assistance from the government because of the unclear status of the land.

On the other hand, there are those who disagree with this. This party is actually a part of the committee of the mosque itself. They want the land to be the property of the mosque. The researcher actually did not know for sure the main cause of this dispute because the party claimed to be so firm in declaring his disapproval had long since passed away. The heirs were not too knowledgeable and some were difficult to find. It can only be concluded from the resource person, that the dispute was caused by several things. Among them:

1. The Theory of Principle Negotiation Assume that conflict is caused by incongruous positions and differences in views about conflict by parties experiencing conflict. In this case, there were differences of views between the two parties related to the urgency of land ownership status.

2. The Theory of Human Needs

Assume that rooted conflicts are caused by basic human needs physical, mental, and social - that are not met or hindered. The DDI's intention to clarify the status of this land was borne by other parties. The status of ownership of the land itself is a very essential thing for madrasas to get recognition from the government.

This dispute initially caused inappropriate actions and even tended to be anarchic. Madrasas often get threats from unknown parties, creating fear and discomfort. This also triggered DDI to clarify the problem and resolve the dispute as soon as possible. As a first step, they 
initiated the resolution of the case through deliberation outside the court.

\subsubsection{Mediation of Conflict Resolution}

1. Mediation Concept

Etymologically, the term mediation comes from Latin, mediare which means being in the middle. This meaning refers to the role displayed by a third party as a mediator in carrying out his task of mediating and resolving disputes between parties. 'Being in the middle' also means that the mediator must be in a neutral and impartial position in resolving disputes. He must be able to protect the interests of the parties disputes fairly and equally, thereby fostering trust from the parties to the dispute (Abbas, 2009).

Mediation is one form of dispute resolution effort termed Alternatve dispute Resolution (ADR). ADR is an effort to resolve disputes through outside court or non-litigation cooperation. Settlement of out-of-court disputes first appeared in the United States (Harahap, 1997). This arises because the United States feels that dispute resolution through the litigation process (the judiciary) cannot fulfill a sense of justice and dissatisfaction with the judicial system (dissatisfied with the judicial system) for the people who are parties to the dispute. This difference in settlement of disputes outside the court is an alternative that can be chosen in resolving disputes arising from the development of existing conflicts. This method also continues to grow in various countries around the world which finally arrived in Indonesia also growing rapidly along with technological developments that continue to propagate in people's lives. With the ease and benefits that can be felt by the parties to the dispute, justice seekers will certainly be interested.

Mediation places more emphasis on the existence of third parties that bridge the disputing parties to resolve their disputes. This explanation is very important to distinguish from alternative forms of resolving other disputes such as arbitration, negotiation, adjudication, etc. The mediator is in a 'middle and neutral' position between the parties to the dispute, and seeks to find a number of agreements so that the results are 
satisfying the parties to the dispute. mediation as expeditiously as possible "

Mediation clearly involves third parties (both individuals and in the form of an independent institution) that are neutral and impartial, which will function as mediators. As a third party that is neutral, independent, impartial and appointed by the parties, the mediator is obliged to carry out their duties and functions based on the willingness and integrity of the parties. As a party outside the court, the mediator does not have compulsive authority. disputes to seek input on the subject matter in dispute. Based on the information obtained, then the mediator can determine the case, the weaknesses and strengths of each party, then try to prepare a proposal for completion which is then communicated to the parties directly. The mediator must be able to create a conducive atmosphere for the creation of a compromise between the two parties to obtain win-win results. After obtaining the agreement from the parties on the proposal submitted (with all changes) in resolving the problem, the mediator draws up an agreement written to be signed by the parties. Not only that, the mediator is expected to assist in the implementation of the written agreement as a decision of the mediation process that has been carried out.

At the beginning of the year, the Regional Board of the DDI Parepare City Mr. Ibrahim initiated conflict resolution through mediation. He also proposed that Mr Alam Tahir be a mediator, which was then approved by all parties. This mediation is carried out in 3 stages, pre-mediation, the execution of mediation and the implementation of mediation.

2. Mediation Stages

a. Pre-mediation

Mr Alam Contact the parties. The contacted party included Mr. Idris as chairman of the representative of DDI. La Tuka as chairperson of the other party. He explored and provided initial information on mediation. The mediator looks for evidence relating to the status of the land. The evidence is held by Ustaz 
Said. The purpose of the meeting planned at that time was to have a win-win solution agreed by both parties. Mediation was held at the residence of $\mathrm{Mr}$ Alam Tahir

b. Execution

Mediation is opened by Mr Alam Tahir directly without any specific ceremonies. Then the Mediator provides an opportunity for all parties to present their respective presentations. Ust. Said stated the story of the beginning of the waqf. Likewise with La Tuka. DDI stated the urgency of land ownership for the administration and recognition of DDI madrasas. Some of the mosque administrators expressed their suspicions about DDI authorities later on the status of the land. Mr Said dismissed the suspicion by stating that the status of the mosque's land had become a land of ownership, not a waqf land anymore. So the status will not change. Whereas the madrasa land is still State land. He showed the land certificate complete with the plan.

The mediator concludes that this problem is a form of misunderstanding and a difference in perception. Options are offered. Among these options are:

1. The DDI gets its legal status.

2. DDI parties obtain building use rights. Land status only as waqf land

3. The DDI party gets use rights. The status of the land is still owned by the State.

Initially, the first option is likely to become an agreement. It's just that there is no involvement of the Land Agency who knows more about this so that this option is suspended first. The option which eventually becomes a temporary agreement is the third, while learning more about the implications of the other options from the authorized institution. Another agreement that occurs is that there are no 
more forms of threats from one party to the other. Although the agreement is not the main choice of DDI, they still accept it because it is arbitrary and there is still a continuation of the next stage of mediation.

3. Implementation

Not all mediations can run smoothly and in accordance with the expected wishes. As happened in the mediation this time, the desire of the first party to make the land into ownership rights has not been implemented. But the thing that is no less essential, namely peace, can be achieved by both parties. In peace carried out by both parties who will be able to reach an agreement the results of this agreement are referred to as a peace agreement, whereas if peace is carried out in the manner and mediation process the results of the agreement will be obtained, namely a mediation agreement.

The mediator here explains that the legal consequences of mediation, which later the parties can choose the best and the bad ones. The purpose of this mediation has been achieved. The existence of a peace agreement was established and the certainty of the status of the land by the Labukkang DDI Madrasah.

\subsection{Mediation on various Perspectives}

\subsubsection{Mediation in Islam}

Nimer (2003) formulated 12 principles for resolving disputes (conflicts) that were built by the Qur'an and practiced by the Prophet Muhammad. The mediation carried out in resolving this dispute when examined in an Islamic perspective, will contain the following points:

\begin{tabular}{|l|l|l|}
\hline No. & Islamic Principles & Mediation \\
\hline $\mathbf{l}$ & Justice & $\begin{array}{l}\text { The mediator has realized his justice by } \\
\text { truly acting as a neutral party. It is also } \\
\text { proven by giving each party the } \\
\text { opportunity to channel their aspirations } \\
\text { in a balanced manner. The mediator also } \\
\text { gives a decision that is equally } \\
\text { acceptable to each party. The rights of } \\
\text { both parties are fulfilled. }\end{array}$ \\
\hline
\end{tabular}




\begin{tabular}{|c|c|c|}
\hline 2. & Social & $\begin{array}{l}\text { The mediator has carried out his duties } \\
\text { with Khair and Ihsan. This is indicated } \\
\text { by the treatment of both parties in a fair, } \\
\text { good and wise manner. }\end{array}$ \\
\hline 3. & Universal & $\begin{array}{l}\text { It does not favor a mediator against one } \\
\text { party because of its status and position } \\
\text { in society is proof that the mediator } \\
\text { really has preserved his dignity as } \\
\text { mediator, and also treats the parties }\end{array}$ \\
\hline 4. & Equal & $\begin{array}{l}\text { Mediator views everyone in the same } \\
\text { position in law. So that the mediator's } \\
\text { treatment in providing legal assistance } \\
\text { does not take into account ethnic, rank } \\
\text { and certain groups. }\end{array}$ \\
\hline 5. & Protecting Human Life & $\begin{array}{l}\text { Islam not only prohibits the elimination } \\
\text { of the human soul, but Islam also } \\
\text { prohibits the destruction of resources } \\
\text { that sustain human life. }\end{array}$ \\
\hline 6. & Achieving Peace & $\begin{array}{l}\text { Communication is important in } \\
\text { resolving disputes. Direct } \\
\text { communication between parties will be } \\
\text { more productive in resolving disputes. } \\
\text { Third parties are an integral part of } \\
\text { peaceful building interventions by } \\
\text { facilitating communication, avoiding } \\
\text { tension, and helping to improve } \\
\text { relationship relations. }\end{array}$ \\
\hline 7. & Basic on Knowlodge & $\begin{array}{l}\text { The mediator has carried out dispute } \\
\text { resolution in accordance with applicable } \\
\text { standards. His ability to lead and } \\
\text { provide options that are agreed upon is a }\end{array}$ \\
\hline
\end{tabular}




\begin{tabular}{|l|l|l|}
\hline & & $\begin{array}{l}\text { reflection of the mediation of the } \\
\text { knowledge and logic of the mediator. }\end{array}$ \\
\hline $\mathbf{8 .}$ & Creative and Innovative & $\begin{array}{l}\text { Creativity and innovation can give birth } \\
\text { to new choices that help achieve } \\
\text { compromise with a sense of justice. } \\
\text { Innovation is born from the results of } \\
\text { mediator ijtihad. mediator able to realize } \\
\text { peaceful efforts through; dialogue, } \\
\text { mediation, nonviolent mobilization. }\end{array}$ \\
\hline 9 & Forgiveness & $\begin{array}{l}\text { After the peace agreement was realized, } \\
\text { both parties finally forgave each other. }\end{array}$ \\
\hline $\mathbf{1 0}$ & Accountability & $\begin{array}{l}\text { All parties must maintain the results of } \\
\text { the mediation decision responsible for } \\
\text { not violating it. }\end{array}$ \\
\hline $\mathbf{1 1 .}$ & Collaborative & $\begin{array}{l}\text { Both parties consciously and responsibly } \\
\text { maintain the mediation process led by } \\
\text { the mediator. Both parties also maintain } \\
\text { the results of the mediation decision } \\
\text { together. }\end{array}$ \\
\hline $\begin{array}{l}\text { Peace manifested the results of forum } \\
\text { participation through an open process. }\end{array}$ \\
\hline
\end{tabular}

\subsubsection{Local Bugis Norm}

Bugis custom norms are represented in 5 (five) items
Pangngadereng. In this perspective, mediation contains the following points (Mattulada, 1988):

\begin{tabular}{|l|l|l|}
\hline No. & Local Bugis Norm & Mediation \\
\hline $\mathbf{1 .}$ & Ade' & $\begin{array}{l}\text { This dispute resolution embodies justice } \\
\text { and peace which are basic human rights. }\end{array}$ \\
\hline $\mathbf{2 .}$ & Bicara & $\begin{array}{l}\text { Bicara is the rules of justice in a broad } \\
\text { sense. Mediation carried out refers to the } \\
\text { applicable law in Indonesia which is } \\
\text { strengthened by technical instructions } \\
\text { by the authorized institution. }\end{array}$ \\
\hline
\end{tabular}




\begin{tabular}{|l|l|l|}
\hline 3. & Rapang & $\begin{array}{l}\text { The results of the agreement have } \\
\text { provided certainty so that there are no } \\
\text { expected actions that disturb order and } \\
\text { justice. }\end{array}$ \\
\hline 4. & Wari & $\begin{array}{l}\text { Mediator has the authority that has been } \\
\text { regulated by the Law and technical } \\
\text { guidance. Mediators carry out their } \\
\text { responsibilities under the applicable } \\
\text { rules. }\end{array}$ \\
\hline 5. & Sara & $\begin{array}{l}\text { Sara is a system that regulates where a } \\
\text { king in running his government must rely } \\
\text { on God. This mediation has also relied on } \\
\text { and is based on rules based on religion. } \\
\text { This can be seen in the previous } \\
\text { discussion. }\end{array}$ \\
\hline
\end{tabular}

\section{Conclusion}

Based on the results of the research and the subject matter discussed by the author above, the following conclusions can be taken

1. The dispute is caused by the first, Principle Negotiation. in this case, there were different views between the two parties related to the urgency of land ownership status. Second, Human Needs Theory. The DDI's intention to clarify the status of this land was borne by other parties. The status of ownership of the land itself is a very essential thing for madrasas to get recognition from the government.

2. This mediation is carried out in 3 stages, pre-mediation, the implementation of mediation and the implementation of mediation. During pre-mediation, Bapak Alam Tahir drew up steps to begin the mediation process, contacted and summoned representatives of both parties. In the implementation of the mediation, Mr Alam Tahir began, giving the opportunity to the DDI and the mosque management to explain the story, giving an option agreed by both parties. The 
implementation of this mediation is that both parties agreed to a peace agreement. The implementation of the Land Registration Object has not been carried out. This mediation also contains 12 points that are in accordance with the religious perspective and 5 points according to the traditional norms of the Bugis.

\section{Suggestion}

\subsection{For the Mediators}

1. It is better to become a mediator to master and understand about civil cases that are resolved by means of mediation

2. It is expected that all judges in Indonesia in handling civil disputes are required to have a certificate to become a mediator.

3. Within forty working days the mediator is required to be able to conduct mediation as well as the mediator must be able to formulate a plan so that the trial can run smoothly and in accordance with the expectations of the parties and it is hoped that the results will not disappoint the parties.

\subsection{For the dispute parties}

1. The parties to the dispute are expected to attend mediation according to a predetermined schedule. The good faith of the parties is expected to produce good decisions.

2. The importance of the peace agreement is to guarantee the legal certainty of the parties and to avoid future disputes.

\section{REFERENCES}

Al-Qur'an and its traslation

Azzam.Abd. Aziz Muhammad, Fiqh Mu'amalat, Cairo: Maktabah alRisalah adDauliyah, Fak. Syari'ah Islamiah Univ. al-Azhar, CairoMesir, 1998

Fisher. Simon, dkk, Mengelola Konflik: Keterampilan dan Strategi Untuk Bertindak, Cetakan Pertama, Alih Bahasa S.N. Kartikasari, dkk, Jakarta: The British Counsil, Indonesia, 2001

Fred R. Kerlinger, Foundation of Behaviour Research, Cet. XII; Newyork: Holt Rinehart and Winston Inc., 1973

Hadi. Sutrisno, Metodologi Research, jilid I, Cet. XX; Yogyakarta: Audi Ofsser, 1987

James A. Black dan Dean J. Champion, Metode and Sosial Research, Alih Bahasa E. Koeswara, Metode dan Masalah Penlitian Sosial, Bandung: Rifika Aditama, 1999.

Jones. Tricia S. and Dan Kmitta, School Conflict Management: Evaluating Your Conflict Resolution Education Program, Ohio: Ohio Commission on Dispute Resolution \& Conflict Management, 2001 
Kamus Besar Bahasa Indonesia, Jakarta: Balai Pustaka, 2005

Khathib. Muhammad, Al-lqna',jilid I, Beirut: Dar AI-Ma'rifah 1974

Koentjaraningrat, Metode-metode Penelitian Masyarakat, Jakarta: Gramedia, 1993

Levine. Stewart, Getting to Resolution, Turning Conflict into Collaboration, San Fransisco: Berrett Koehler Publishers Inc, 1998

Lexy J. Moeloeng, Metodologi Penelitian Kualitatif, Bandung: Rosdakarya, 1989

Mardalis, Metode Penelitian: Suatu Pendekatan Proposal, Jakarta: Bumi Aksara, 2004

Mindes. Gayle, Teaching Young Children Social Studies (United States of America: Praeger Publishers, 2006

Moh. Nazir, Metode Penelitian, Cet. III; Jakarta: Ghalia Indonesia, 1988

Morton.Deutsch and Peter T. Coleman, The Handbook of Conflict Resolution, Theory and Practice, San Fransisco: JosseyBass Publisher, 2006

Muhajir. Noeng, Metodologi Penelitian Kualitatif, Yogyakarta: Rake Sarasin, 1996

Munawar. Said Agil Husin, Hukum Islam dan Pluralitas Sosial, Jakarta: Penamadani, 2004

Narwoko. J. Dwi dan Bagong Suyanto, Sosiologi Teks Pengantar dan Terapan, Jakarta: Kencana Prenada Media Group, 2005

Scanell. Mary, The Big Book of Conflict Resolution Games, United States of America: McGraw-Hill Companies, Inc, 2010.

Setiadi.lly M. dan Usman Kolip, Pengantar Sosiologi Pemahaman Fakta dan Gejala Permasalahan Sosial: Teori,
Aplikasi, dan Pemecahannya, Jakarta: Kencana Prenada Media Group, 2011

Soekanto.Soerjono, Kamus Sosiologi, Jakarta: PT. Raja Grafindo Persada, 1993

Sutrisno dkk, Metodologi Research Yogyakarta: Yayasan Penerbit Fakultas Psikologi UGM, 2004

Syarbiny, Mughni AI-Muhtaj, Juz. 10, Kairo : Musthafa Al-Halaby,1972

Vreden. Berg, Merode dan Tehnik Penelitian Masyarakat, Jakarta: Gramedia, 1978

Winarto Suracmad, Pengantar Penelitian Ilmiah, Bandung: Tarsito, 1990

Wiradi.Gunawan, Pola Penguasaan Tanah dan Reforma Agraria, dalam Sediono M.P. Tjondronegoro \& Gunawan Wiradi (penyunting). Dua Abad Penguasaan Tanah: Pola Penguasaan Tanah Pertanian dari Masa ke Masa, Jakarta: Yayasan Obor Indonesia dan PT Gramedia,1984

Zeitlin. Irving M, Memahami Kembali Sosiologi, Yogyakarta: Gajah Mada University Press, 1998

Zuhali. Wahbah, al-Fiqhu al-Islami Wa Adillatuhu, Damaskus: Dar al-Fikri al Mu'ashir, 1973 